\title{
Copper Ion Doped Mullite Composite in Poly (vinylidene Fluoride) Matrix: Effect on Microstructure, Phase Behavior and Electrical Properties
}

\author{
Kumaresh Halder ${ }^{1}$, Biplab Kumar Paul ${ }^{1}$, Biswajoy Bagchi ${ }^{2}$, Alakananda Bhattacharya ${ }^{1}$ and \\ Sukhen Das ${ }^{1, *}$
}

${ }^{1}$ Department of Physics, Jadavpur University, Kolkata- 700 032, India

${ }^{2}$ Fuel Cell and Battery Division, Central Glass and Ceramic Research Institute, Kolkata 700032, India

\begin{abstract}
Highly crystallized copper ion doped mullite composites have been synthesized at $1100^{\circ} \mathrm{C}$ and $1400^{\circ} \mathrm{C}$ via solgel technique with five different strengths of copper ion and was incorporated in poly-vinylidene fluoride (PVDF) to make doped mullite composite/polymer films. We have studied the effects of this dopant on microstructure, phase transformation, and electrical properties of the polymer films over a wide range of frequency from $1.0 \mathrm{KHz}$ to $2.0 \mathrm{MHz}$. Characterizations were done by various analytical tools at room temperature. Prominent mullite phases were observed from XRD, FTIR spectroscopy and FESEM characterization of composite polymer. The concentration of the dopant and the sintering temperature were found to be the two basic factors which affect the phase transition of the polymer. The composite film showed maximum dielectric constant of 19.96 at $1 \mathrm{KHz}$ for $1.2 \mathrm{M}$ concentration of copper ion doped mullite sintered at $1400^{\circ} \mathrm{C}$, compared to 3.09 for the pure polymer. Furthermore, both dielectric constant and electrical conductivity of the composite were found to be highly frequency and temperature dependent. After doping, the A.C. conductivity of the composite was found to increase with increasing temperature following Jonscher's power law and the electrical resistivity reduced too. Moreover, the results revealed that the phase behaviors and micro structural changes of the copper ion doped mullite composite/polymer film affected its electrical properties with possible impact on its applications.
\end{abstract}

Keywords: Polymer, Mullite, Sol-gel technique, XRD, FTIR, Dielectric properties, FESEM.

\section{INTRODUCTION}

Polymorphism is an essential characteristic of Poly vinylidene fluoride (PVDF). PVDF is a semi-crystalline polymer having four crystal polymorphs referred to as $\alpha, \beta, y$ and $\delta$ phases $[1,2]$. Conventional melt and solution processing usually result in $\alpha$ phase which has trans-gauche-trans-gauche (TGTG) chain conformation $[3,4]$. $\beta$ phase has all trans (TTTT) zigzag chain conformation; formation of this phase in PVDF is dependent on stretching of the film as well as the preparation temperature $[5,6] . \quad \mathrm{Y}$ phase has TTTGTTTG' chain conformation which can be achieved by either casting from dimethyl sulfoxide (DMSO) or dimethylformamide (DMF) solution regardless of preparation temperature [7]. High electric field, high pressure and annealing temperatures are also responsible for producing $\mathrm{Y}$ phase [8-11].

The main advantage of polymer matrix over ceramic materials is its mechanical quality and it can also be synthesized easily. It has been observed that pure polymer matrix possesses large breakdown strength, good flexibility and great mechanical strength; it is easy

*Address correspondence to this author at the Department of Physics, Jadavpur University, Kolkata- 700 032, India; Tel: +91 9433091337;

E-mail: sukhenjudas@gmail.com to process but has a very low dielectric constant [1214]. On the other hand, ceramic composites generally suffer from brittleness which can be reduced to a commendable extent by integrating ceramic composites into the polymer matrix. Micro scale ceramics of high dielectric constant are used as fillers in polymer to increase its dielectric constant [15-17]. For such composites, filler loadings should be high enough for attainment of that range of dielectric constant that is high enough for industrial applications purposes. Though the electrical resistivity of polymer is quite high which makes it suitable to be categorized as an insulator still its electrical properties could be enhanced by incorporation of fillers in polymeric matrix as these fillers interact with the polymer chains. Thus these composites have the ability to exhibit new properties that single phase materials do not possess [18].

Thus, novel composites with comparatively high capacitance, high-energy storage density, and small volume can be prepared, which are known to be very useful materials for varieties of applications in electronics such as, transducers, hydrophones, piezosensors, high-charge storage capacitors [19], etc.

Roy et al. synthesized highly crystallized mullite composite at $1000^{\circ} \mathrm{C}$ and $1300^{\circ} \mathrm{C}$ via sol gel technique 
in the presence of transition metal ions such as cobalt, nickel and copper. The results showed with increase in concentration of metals, crystallization of mullite was enhanced. The dielectric constant of the composites followed typical trend observed in ceramic materials i.e., decreased with frequency for all the samples attaining constancy at high frequency $(1.5 \mathrm{MHz})$. Similar nature was observed in case of dielectric loss. Doped mullite nanocomposites showed good dielectric properties at high frequency [20].

According to previous reports, doping of copper ion into mullite affects its microstructure, phase transition, and densification behavior. Roy et al. prepared mullite samples doped with $0.002 \mathrm{M}, 0.02 \mathrm{M}, 0.1 \mathrm{M}, 0.15 \mathrm{M}$, and $0.2 \mathrm{M}$ of iron, nickel, and copper ion by sol-gel process, which showed that the density of the doped samples increases with the increase of metal ion concentration as well as with the sintering temperature. Copper doped mullite exhibits the highest density of 2.46 $\mathrm{g} \mathrm{cm}^{-3}$ at $1400^{\circ} \mathrm{C}$ [21].

Priya and Jog [22] were the first to prepare PVDFclay nanocomposites. They observed that the addition of organically modified clay resulted in the formation of the $\beta$-phase instead of the $\alpha$-phase upon melt processing.

Here, objective of our research work is to investigate the effect of copper doped mullite on phase behavior and microstructure of polymer, and also to study its electrical properties.

\section{EXPERIMENTAL PROCEDURE}

\section{Materials}

Chemicals used in the preparation of copper doped mullite precursor gels are: Aluminium nitrate nonahydrate $\left[\mathrm{Al}\left(\mathrm{NO}_{3}\right)_{3} .9 \mathrm{H}_{2} \mathrm{O}\right]$ extra pure (MERCK, India), Aluminium isopropoxide $\left[\mathrm{Al}(-\mathrm{O}-\mathrm{i}-\mathrm{Pr})_{3}\right]$ puriss (Spectrochem Pvt. Ltd., India.), Tetra ethyl orthosilicate $\left[\mathrm{Si}\left(\mathrm{OC}_{2} \mathrm{H}_{5}\right)_{4}\right]$ (MERCK, Germany), Copper (II) nitrate trihydrate $\left[\mathrm{Cu}\left(\mathrm{NO}_{3}\right)_{2} \cdot 3 \mathrm{H}_{2} \mathrm{O}\right]$ (MERCK, Germany), PVDF (Sigma-Aldrich) and N,N-Dimethylformamide (DMF) (Sigma-Aldrich).

\section{Methods}

Aluminum isopropoxide ( $\left.\mathrm{Al}(-\mathrm{O}-\mathrm{i}-\mathrm{Pr})_{3}\right)$ and aluminum nitrate nonahydrate (ANN) were used as alumina sources and tetra ethyl orthosilicate (TEOS) as a silica source. Mullite precursor gel solution was prepared by dissolving stoichiometric amounts of aluminium isopropoxide and TEOS in the aqueous solution of aluminium nitrate nonahydrate and stirring it vigorously for 2 hours. The molar ratio of $\mathrm{Al}(-\mathrm{O}-\mathrm{i}-$ $\mathrm{Pr})_{3} / \mathrm{Al}\left(\mathrm{NO}_{3}\right)_{3} \cdot 9 \mathrm{H}_{2} \mathrm{O}$ was kept at $7: 2$ in order to form spinnable sols and the mole ratio of $\mathrm{Al} / \mathrm{Si}$ was $3: 1$. Moreover, $\mathrm{pH}$ of the solution was also maintained at 5 , doped solutions were prepared by adding an aqueous solution of five concentrations of the copper salts- 0.4 $\mathrm{M}, 0.6 \mathrm{M}, 0.8 \mathrm{M}, 1.0 \mathrm{M}$, and $1.2 \mathrm{M}$ to the original solution and stirring it for 90 minutes. The solution takes the gel form after vigorous stirring and overnight heating at $60^{\circ} \mathrm{C}$. The samples were then pelletized and sintered at $1100^{\circ} \mathrm{C}$ and $1400^{\circ} \mathrm{C}$ for 3 hours in a muffle furnace under air atmosphere (heating rate $10^{\circ} \mathrm{C} / \mathrm{min}$.).

To make PVDF solution, PVDF (10wt\%) was dissolved completely in dimethylformamide (DMF), and was stirred at $70^{\circ} \mathrm{C}$ for 6-7 hours. Copper ion doped mullite samples of different strengths were added to the solution and stirred overnight at above mentioned temperature. The films were prepared with mass fractions of copper doped mullite of $20 \%$. Then it was sonicated in a bath type sonicator for an additional hour to further enhance the dispersion and to eliminate air bubbles simultaneously. Then the ultimate solution was cast and incubated in an oven at $70^{\circ} \mathrm{C}$ for $1-2$ hours until film forms. The complete process has been shown in the form of a flowchart in Figure 1.

\section{Investigating Instruments}

The crystalline phases developed in the samples sintered at room temperature were analyzed by X-ray powder diffractometer (model-D8, Bruker AXS, Wisconsin, USA.) using $\mathrm{Cu} \mathrm{Ka}$ radiation- $1.5418 \mathrm{~A}^{\circ}$ and operating at $40 \mathrm{KV}$ with a scan speed of $1 \mathrm{sec}$. /step.

The characteristic stretching and bending modes of vibration of chemical bonds of samples were effectively evaluated by FTIR spectroscopy (FTIR-8400S, Shimadzu) by using air as background from 1200 to $400 \mathrm{~cm}^{-1}$.

Electrical properties such as dielectric permittivity $\left(\varepsilon_{r}\right)$, dissipation factor $(\tan \delta)$, a.c. conductivity $\left(\sigma_{\text {a.c. }}\right)$ and resistivity $(\rho)$ of the samples were measured in the frequency range $20 \mathrm{~Hz}$ to $2.0 \mathrm{MHz}$ using an LCR meter (HP Model 4274 A, Hewlett-Packard, USA). For the measurement of electrical properties silver paste was coated on two extreme surfaces of the film to make them conducting. 


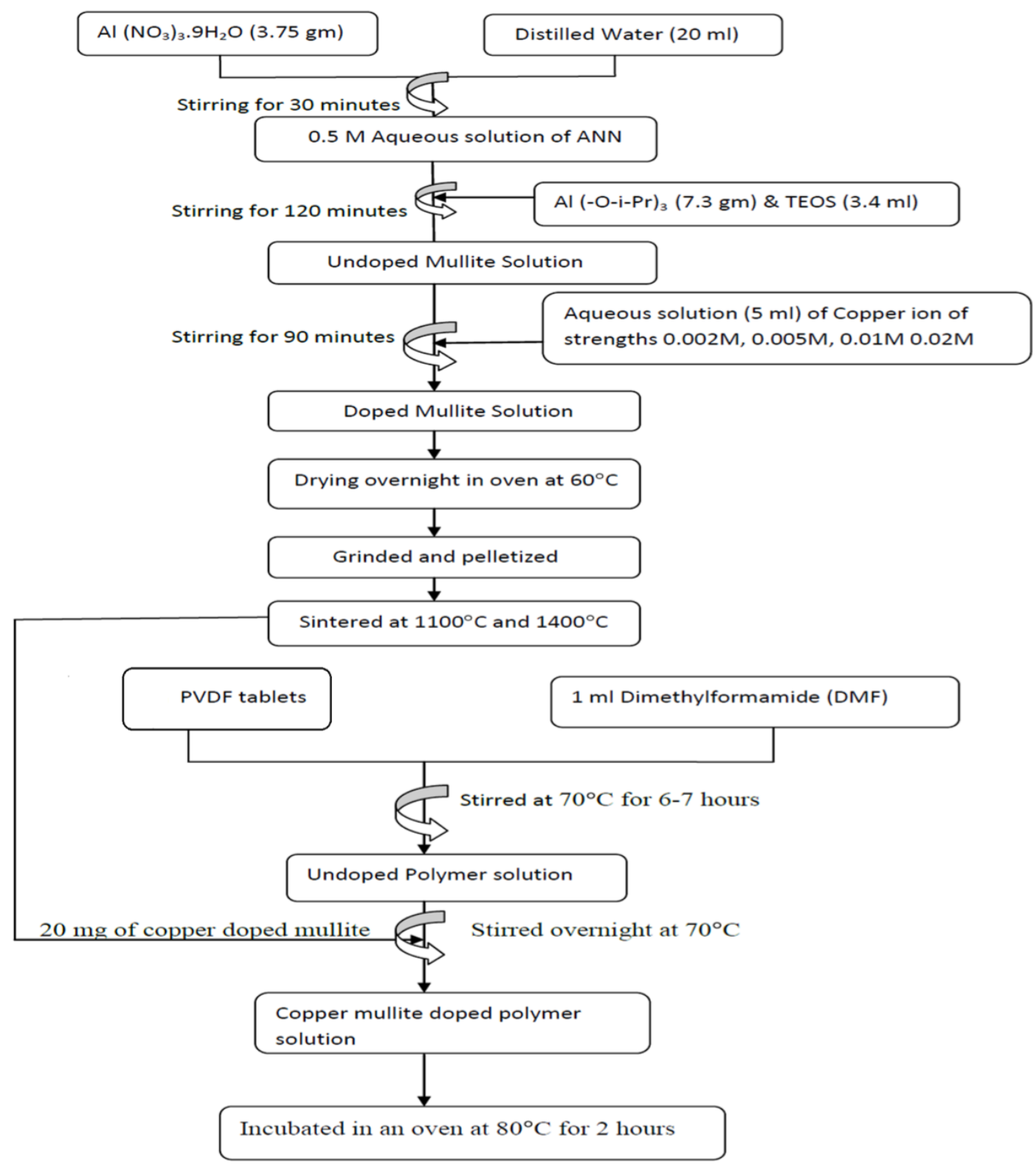

Figure 1: Flowchart depicting formation of copper ion doped mullite composite/polymer film.

The morphology of the sintered gels was studied by Field Emission Scanning Electron Microscope (FESEM) (JSM 6700F, JEOL Ltd. Tokyo, Japan).

\section{RESULTS AND DISCUSSIONS}

\section{X-Ray Diffraction Analysis}

Figure 2 shows the X-ray diffraction pattern of PVDF thin films prepared at $70^{\circ} \mathrm{C}$ using DMF as a solvent. Undoped film $\left(G_{0}\right)$ shows phases at $2 \theta=$ 17.883(100), 20.135(110), 26.728(021), 38.657(131) and $56.877(241)$, where the first three peaks are the footprint of a phase, the peak at 38.657(131) confirms the presence of $y$ phase, and peak at $56.877(241)$ is an additional phase of PVDF [23]. In case of other five composite films, where copper doped mullite composites were sintered at $1100^{\circ} \mathrm{C}$ (Figure 2a) and $1400^{\circ} \mathrm{C}$ (Figure $\mathbf{2 b}$ ), all peaks of undoped films were obtained along with some extra phases of PVDF (JCPDS \# 421650), Mullite (JCPDS \# 421650), Copper aluminum hydroxide silicate (JCPDS \# 84-0388) and Copper oxide (JCPDS \# 80-1917). The peak at $20.8(110)$ is the evidence of $\beta$ phase, and the peaks at $30.960(001), 33.228(220), 35.278(111), 36.993(130)$ and 57.561(041) indicates the existence of mullite in PVDF film [20, 24]. Concentration of copper ions has an overall positive effect on the growth of mullite phases. It can be seen that, in case of Figure $2 \mathbf{a} \beta$ phase was visibly observed for only $1.0(\mathrm{M})$ and $1.2(\mathrm{M})$ 
JCPDS Card Number $15-0776$ ( $M-$ Mullite)

JCPDS Card Number 42-1650 ( $\alpha, \beta, \gamma$ \& other (*) phases of PVDF) JCPDS Card Number 84-0388 (* Copper Aluminum Hyhroxite Silicate)

JCPDS Card Number 80-1917 (- Copper Oxide)

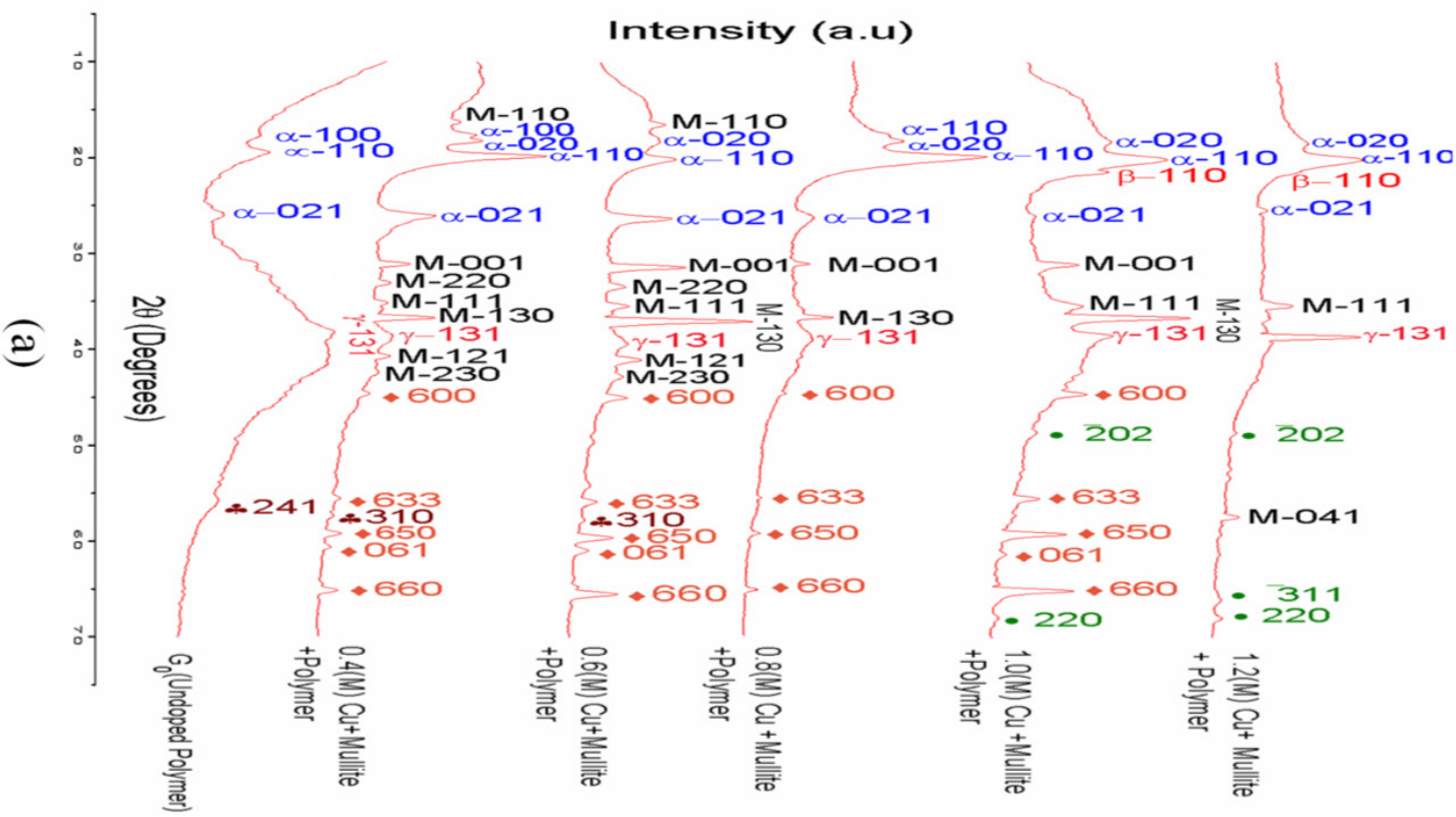

JCPDS Card Number 15-0776 ( M- Mullite)

JCPDS Card Number 42-1650 ( $\alpha, \beta, \gamma$ \& other(*) phases of PVDF) JCPDS Card Number 84-0388 (* Copper Aluminum Hyhroxite Silicate) JCPDS Card Number 80-1917 (- Copper Oxide)

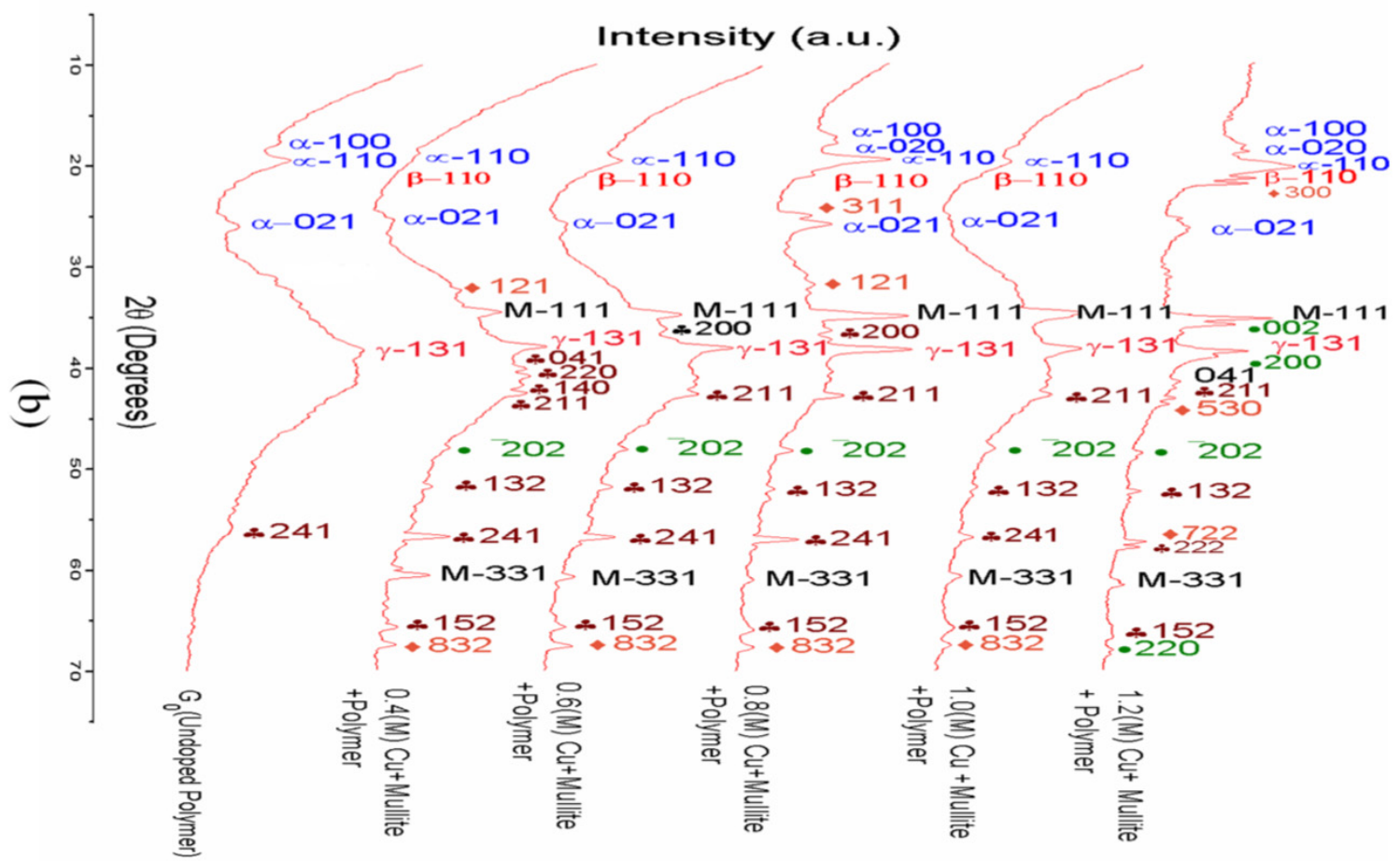

Figure 2: X-ray diffraction pattern of copper ion doped mullite composite/polymer film along with undoped polymer film, where mullite precursor gels sintered at (a) $1100^{\circ} \mathrm{C}$ and (b) $1400^{\circ} \mathrm{C}$.

concentration of copper ion, but in Figure $\mathbf{2 b} \beta$ phase is seen to be present from copper ion concentration of $0.4(\mathrm{M})$ up to $1.2(\mathrm{M})$. From the diffractograms, it was found that with the increase of metal concentration $\left(\mathrm{Cu}^{2+}\right)$ in doped composite, phase transformation in composite increases. Interaction of metal ion doped 
mullite with the polymer matrix is responsible for the accelerated transformation to polymer phases. Phase transformation was not only dependent upon the metal ion concentration, but also upon the sintering temperature. At $80^{\circ} \mathrm{C}$, where the viscosity of the PVDF solution is comparatively low, the thermal energy is sufficient to rotate $\mathrm{CF}_{2}$ dipoles which results in a motion of the neighboring $\mathrm{CF}_{2}$ groups through the large scale trans $(T)$-gauche $(G)$ conformational change. So, conformers aligned either in TTTT ( $\beta$ phase) or TTTGTTTG' ( $\vee$ phase) form. Therefore, the solutions prepared using DMF solvent at $70^{\circ} \mathrm{C}$ produce polar PVDF films having $\alpha, \beta$ and $y$ phases [25].

\section{FTIR Analysis}

The FTIR spectra of copper ion doped mullite composite/polymer films in the range of $400-1500 \mathrm{~cm}^{-1}$ have been investigated in the transmittance modes shown in Figure 3. Peaks at 490, 530, 612, 677, 763, 796, 970, 1076, 1210, 1383, and $1430 \mathrm{~cm}^{-1}$ are significant for $\alpha$-phase identification [26, 27], where vibration bands at $530 \mathrm{~cm}^{-1}$ stands for CF2 bending, 612 and $763 \mathrm{~cm}^{-1}$ for CF2 bending and skeletal bending, and $970 \mathrm{~cm}^{-1}$ for $\mathrm{CH} 2$ rocking. The peaks at
510,840 and $1275-1279 \mathrm{~cm}^{-1}$ are fingerprints of $\beta$ phase, where vibration bands at $510 \mathrm{~cm}^{-1}$ are due to CF2 bending and $840 \mathrm{~cm}^{-1}$ due to $\mathrm{CH} 2$ rocking correspond to $\beta$-phase [28]. Peaks at 561, 741 and 900 $\mathrm{cm}^{-1}$ signifies the presence of mullite $[20,29]$. These main PVDF characterizing peaks along with mullite peaks are present in all doped samples, indicating that the mullite is distributed among PVDF chains. The molecular vibration peaks of $\mathrm{y}$-phase are very close to $\beta$-phase. Therefore, it is very difficult to separate $y$ and $\beta$ phase using FTIR spectroscopy.

The fraction of $\beta$-phase, $F(\beta)$, can be calculated by the absorption peaks in the FTIR spectra by using the equation:

$$
F(\beta)=\frac{X_{\beta}}{X_{\beta}+X_{\alpha}}=\frac{A_{\beta}}{1.26 A_{\beta}+A_{\alpha}}
$$

where, $X_{\alpha}$ and $X_{\beta}$ are the crystalline mass fractions of $\alpha$ and $\beta$ phase, and $A_{\alpha}$ and $A_{\beta}$ are absorption band intensities for $\alpha$ phase and $\beta$ phase, at wave numbers $763 \mathrm{~cm}^{-1}$ and $840 \mathrm{~cm}^{-1}$ respectively $[16,30]$. The variation of $F(\beta)$ with varying concentration of copper ion sintered at $1100^{\circ} \mathrm{C}$ and $1400^{\circ} \mathrm{C}$ is shown in Figure

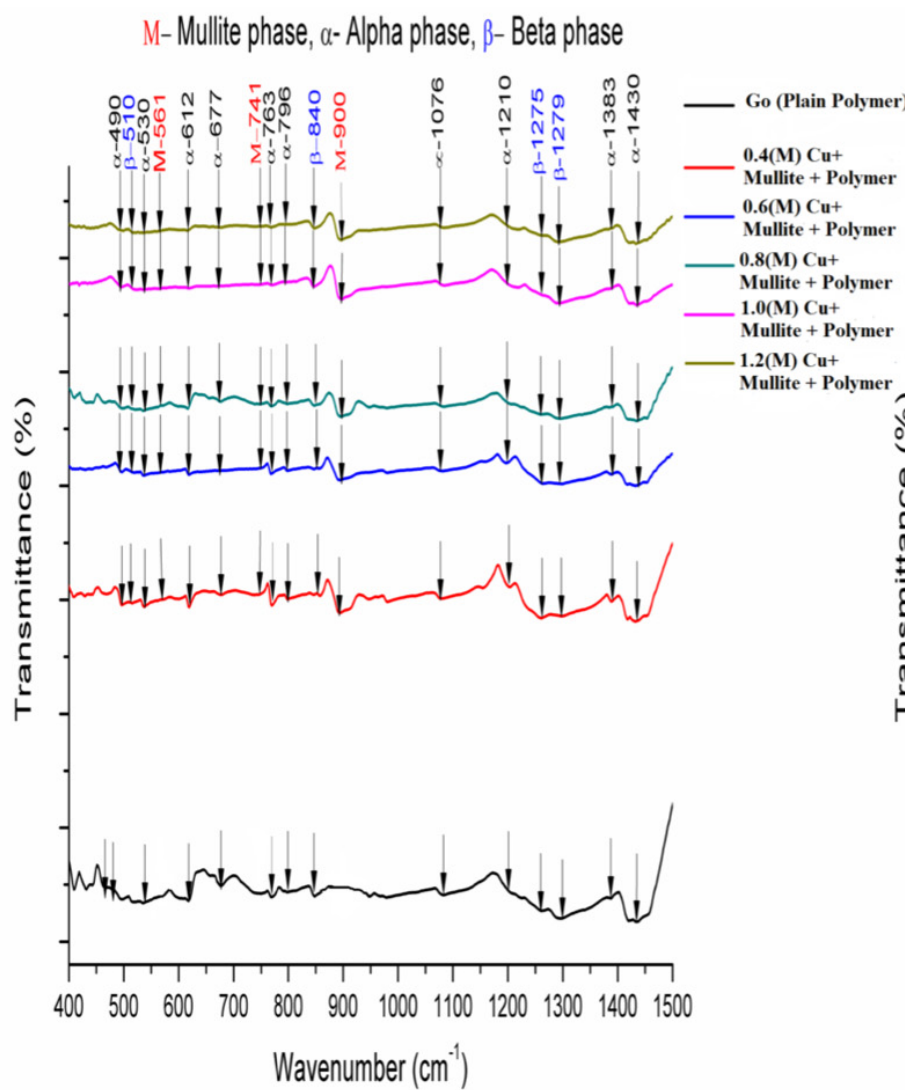

(a)
M-Mullite phase, $\alpha$-Alpha phase, $\beta$ - Beta phase

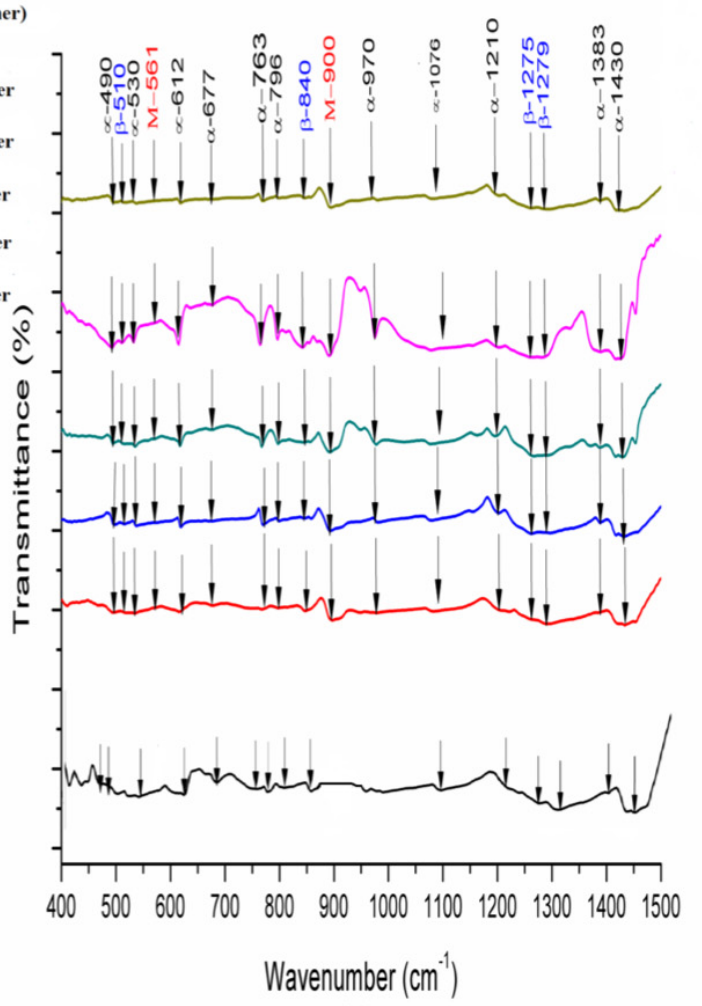

(b)

Figure 3: FTIR pattern of copper ion doped mullite composite/polymer film along with undoped polymer film, where mullite precursor gels sintered at (a) $1100^{\circ} \mathrm{C}$ and (b) $1400^{\circ} \mathrm{C}$. 


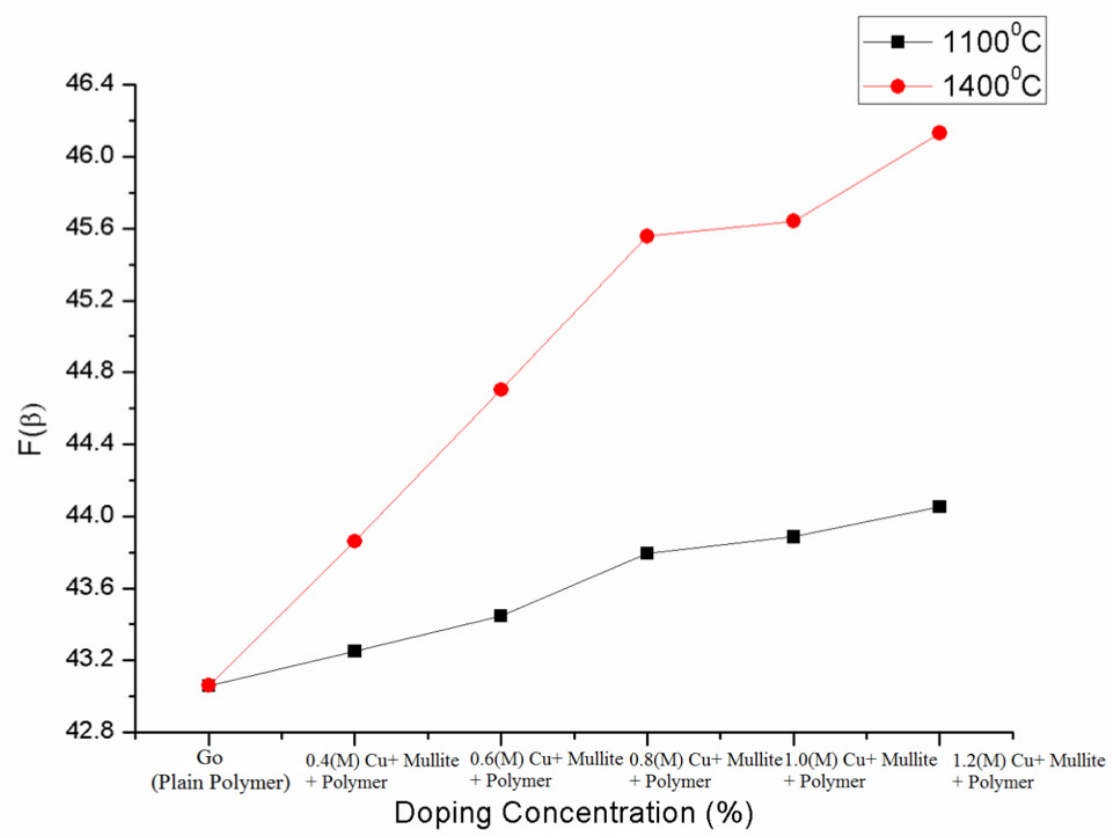

Figure 4: Fraction of $\beta$-phase $(F(\beta))$ with increasing concentration of doped mullite composite, where mullite precursor gels sintered at $1100^{\circ} \mathrm{C}$ and $1400^{\circ} \mathrm{C}$.

4. It can be observed from Figure $\mathbf{4}$ that the addition of copper ion promotes $\beta$ phase with respect to the undoped sample. The maximum amount of $\beta$ phase is observed upon addition of 1.2(M) copper ion doped mullite when sintered at $1400^{\circ} \mathrm{C}$ into the polymer matrix.

\section{Dielectric Study}

\section{Dielectric Constant}

Dielectric measurement of each sample was performed at room temperature in the frequency range $1.0 \mathrm{KHz}$ to $2.0 \mathrm{MHz}$. Figure $\mathbf{5}$ shows the variation in dielectric constant with increase in frequency. The plots clearly show that in both Figures $\mathbf{5 a}$ and $\mathbf{5 b}$, dielectric constant increases with increasing concentration of copper doped mullite composite at the lower frequencies. Theoretically, dielectric behavior of ceramic-polymer systems can be explained qualitatively by permittivity of a composite to a combined dielectric effect of its individual constituents using Logarithmic mixing rule and free charge interruption with the interfaces of heterogeneous insulator/ conductor by Maxwell-Wagner-Sillar(MWS) polarization [31-34]. Good dispersion of copper doped mullite in polymer results in sudden improvement of dielectric properties at a particular frequency as during the procedure charges become entrapped in the interface between PVDF and doped mullite composite. A significant decrease in dielectric constant is observed with increasing frequency. From factual verifications and observations, it has been noticed that for polar materials, initial value of dielectric permittivity is considerably higher, but on increasing the frequency the magnitude gradually drops; the main factor behind this behavior is that the dipoles are unable to follow the field variations at such high frequencies [17].

Dielectric value became $6.58 \& 19.96$ at $1.0 \mathrm{KHz}$ frequency, for 1.2(M) concentration of doped composite, sintered at $1100^{\circ} \mathrm{C}$ and $1400^{\circ} \mathrm{C}$ respectively which are $2.13 \& 6.46$ times higher than that of neat PVDF.

\section{Dielectric Loss}

Figure 6 shows the variation of dissipation factor $(\tan \delta)$ with frequency in the frequency range $1.0 \mathrm{KHz}$ to $2.0 \mathrm{MHz}$ at room temperature. It shows a distinct enhancement in dielectric loss with increasing amount of copper doped mullite composite/ PVDF films. With the gradual increase of doping amount more interfacial areas are created and PVDF polymer chains are separated into smaller domains by the increasing conductive network.

Thus, more molecules or dipoles can rotate, leading to more active movement and more energy dissipation. As we know that dielectric loss is a measurement of energy dissipation from the movement or rotation of the molecules in the alternative electric field, therefore, as the amount of doped composite increased, even more interfacial area and smaller or thinner domains of 


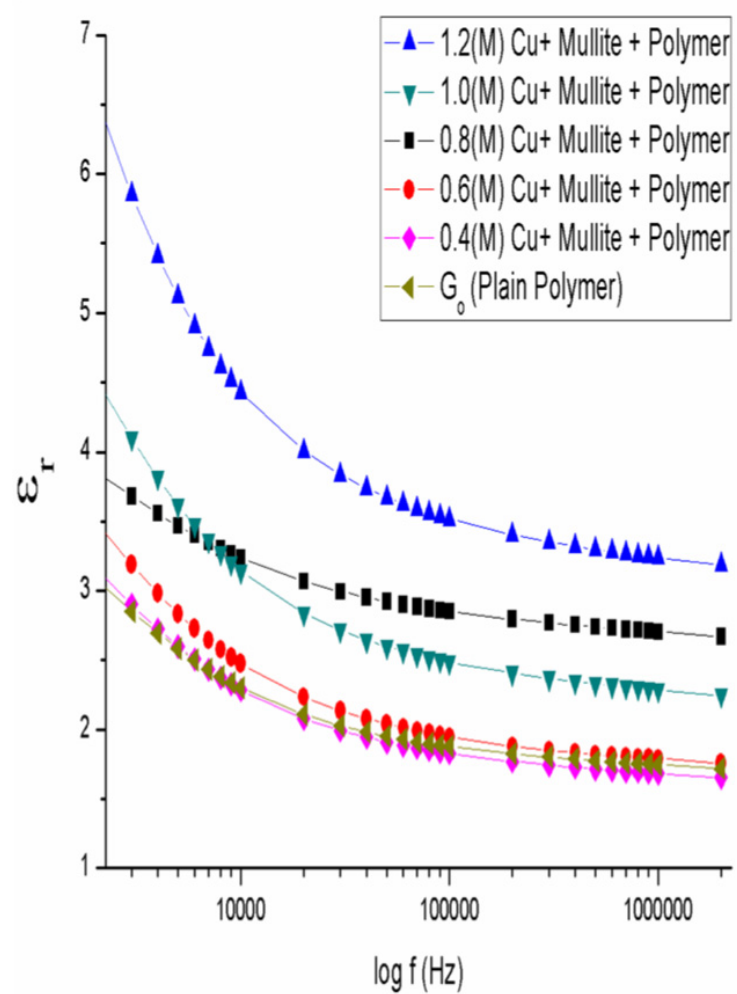

(a)

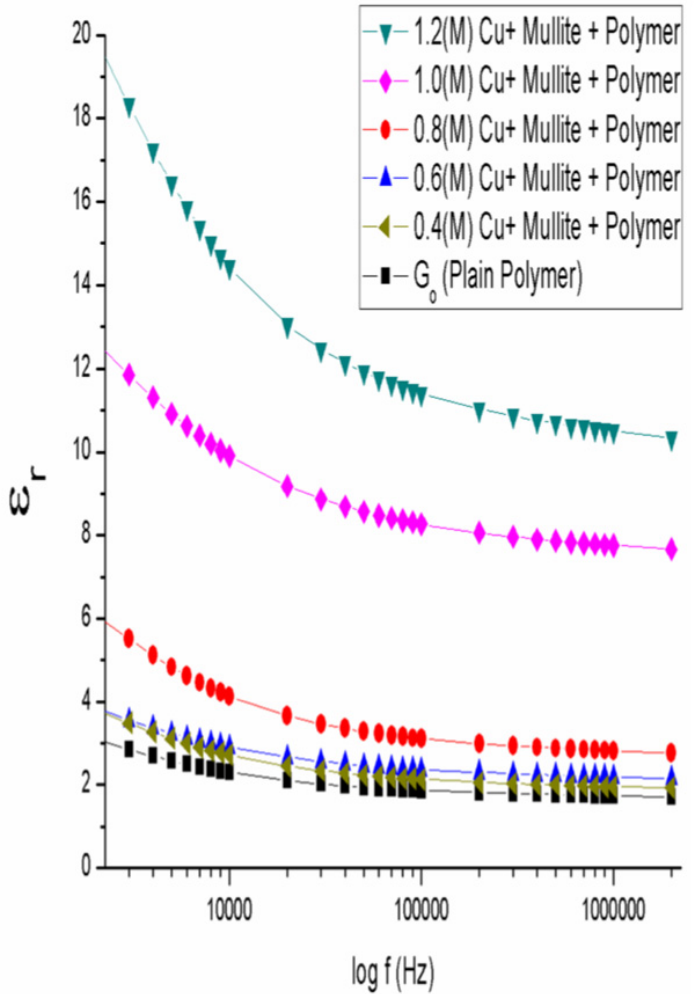

(b)

Figure 5: Frequency response of dielectric constant value $\left(\varepsilon_{r}\right)$ of copper ion doped mullite composite/polymer film along with undoped polymer film, where mullite precursor gels sintered at (a) $1100^{\circ} \mathrm{C}$ and (b) $1400^{\circ} \mathrm{C}$.

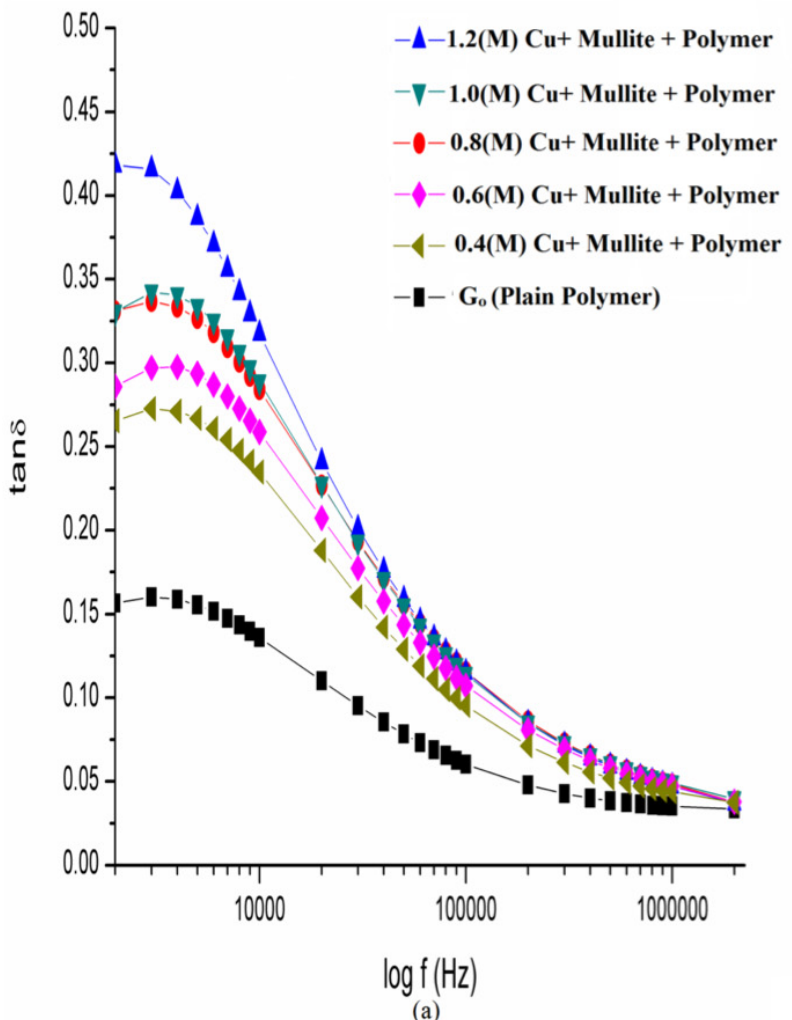

(a)

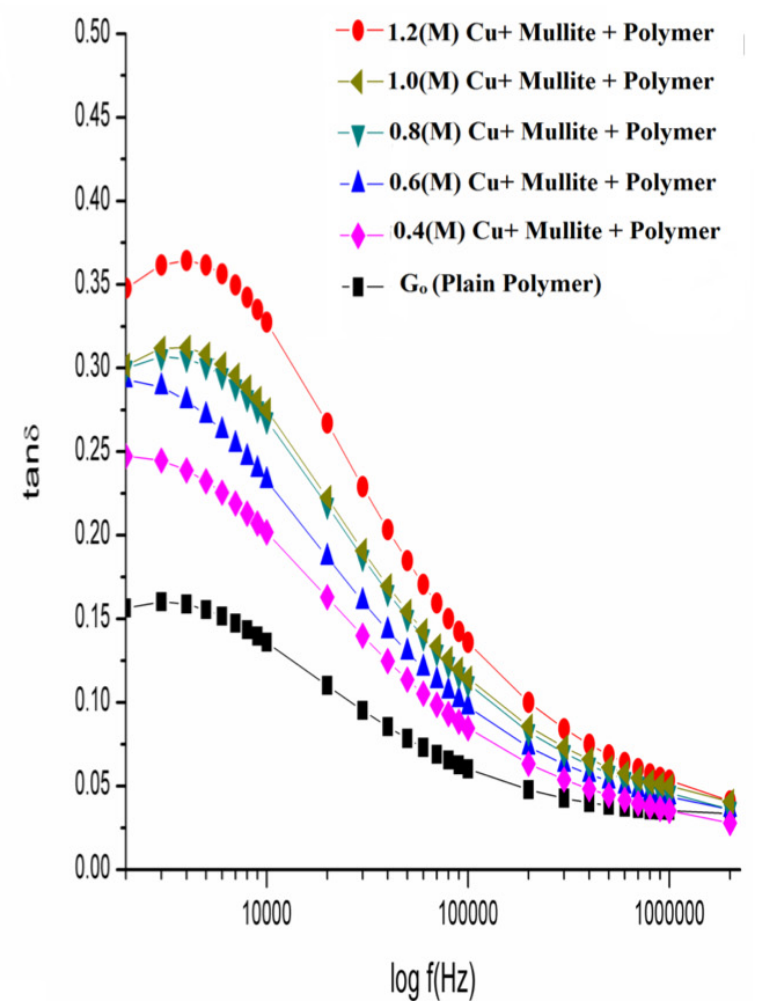

(b)

Figure 6: Frequency response of dielectric loss tangent (tan $\delta$ ) of copper ion doped mullite composite/polymer film along with undoped polymer film, where mullite precursor gels sintered at (a) $1100^{\circ} \mathrm{C}$ and (b) $1400^{\circ} \mathrm{C}$. 


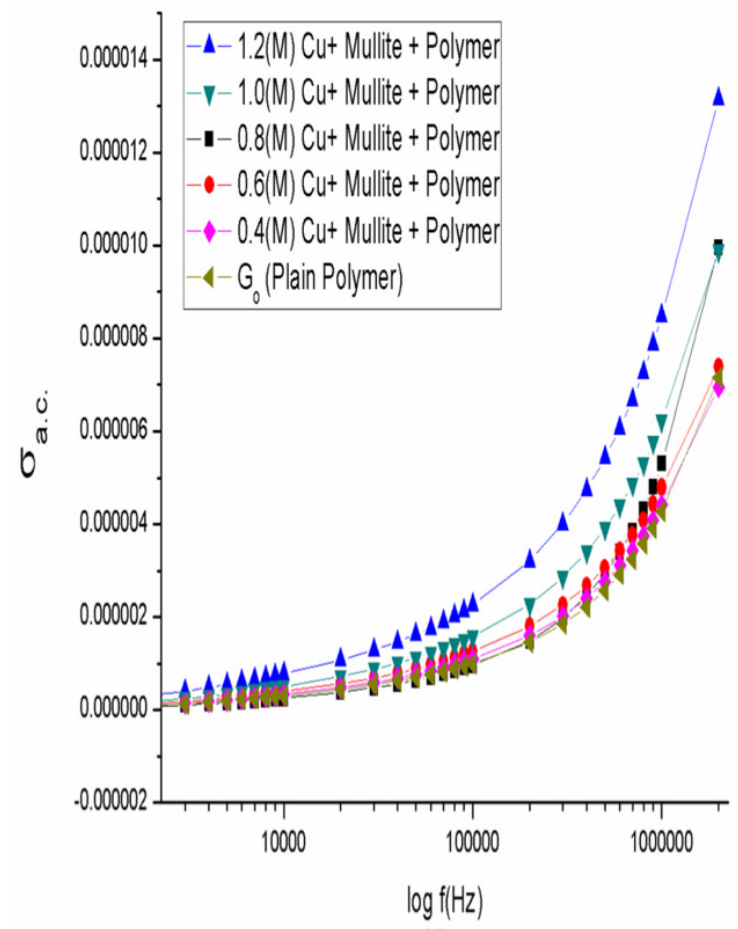

(a)

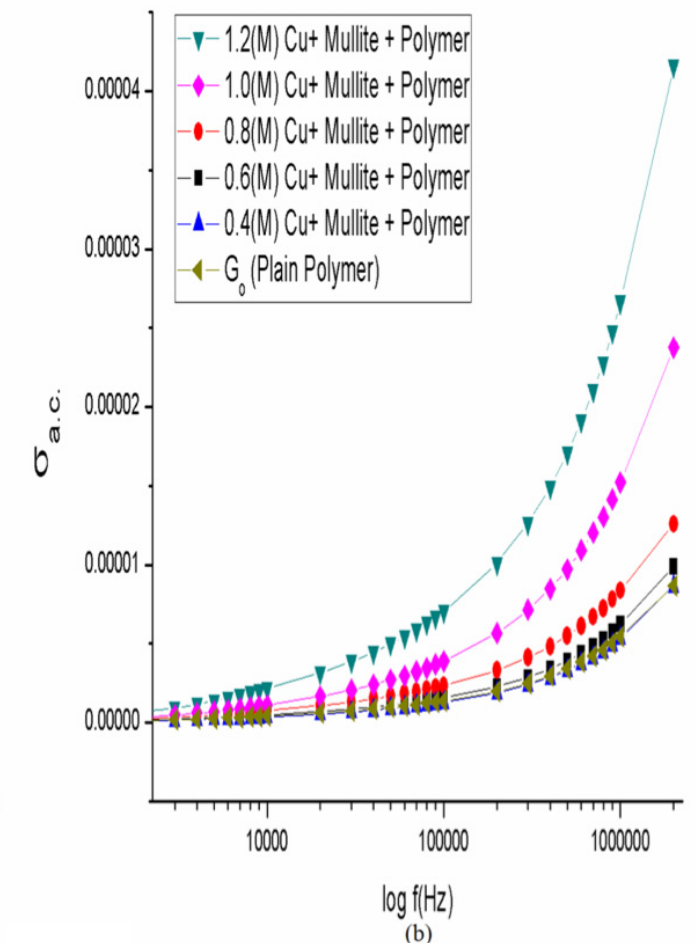

(b)

Figure 7: Frequency response of A.C. conductivity value $\left(\sigma_{\text {a.c. }}\right)$ of copper ion doped mullite composite/polymer film along with undoped polymer film, where mullite precursor gels sintered at (a) $1100^{\circ} \mathrm{C}$ and (b) $1400^{\circ} \mathrm{C}$.

PVDF polymer chain could be observed. Consequently, the enhanced movement of PVDF molecules may induce dielectric loss [24, 31, 35].

\section{Electrical Study}

\section{A.C. Conductivity Analysis}

The A.C. conductivity response with frequency range between $1.0 \mathrm{KHz}$ to $2.0 \mathrm{MHz}$ at room temperature is shown in Figure 7. The A.C. conductivity has typical frequency dependence for all the samples, including pure PVDF which was found to increase with the increase in doping in the doped composite.

Electrical conductivity $\left(\sigma_{\text {total }}(\omega)\right)$ consists of two parts: A.C. conductivity $\left(\sigma_{a . c .}(\omega)\right)$ and D.C. conductivity $\left(\sigma_{\text {d.c. }}\right)$. The frequency of the electric field varies during A.C. conductivity whereas it remains constantin case of D.C. conductivity. $\sigma_{\text {d.c. }}$ depends strongly on temperature and dominates at lower frequency and higher temperatures, where, $\sigma_{\text {a.c. }}(\omega)$ has a dependence on temperature and dominates at higher frequency and lower temperatures. The relation for frequency dependent ac conductivity is

$$
\sigma_{\text {a.c. }}(\omega)=A \omega^{s},
$$

where, $\mathrm{A}$ is constant, $\mathrm{S}$ is a function of temperature, value of which lies between 0 and $1[15,36]$.
The A.C. conductivity increases with increase in frequency, and the response is better for the samples sintered at $1400^{\circ} \mathrm{C}$ as temperature is the common response of polar polymer. As the temperature increases, the polymer becomes soft and the main chain segments become mobile as well as facilitating easier rotation of side chains. Thus, at higher temperatures more and more dipoles are oriented resulting in higher equivalent surface charge density, i.e., the conductivity increases [37] with increase in temperature.

\section{Resistivity Analysis}

For heat sink and electrical contact applications, thermal conductivity is the most important property, but this property is not easy to measure due to large experimental errors. Here, resistivity was selected in this study asit is easy to measure and can be translated into thermal conductivity via WiedmannFrantz equation:

$$
\gamma / \sigma=L T
$$

where, $\mathrm{Y}$ is thermal conductivity, oiselectrical conductivity, $L$ is Lorenz number, which is constant for all metals $\left(2 \times 10^{-8} \quad \mathrm{~W} \Omega \mathrm{K}^{-2}\right)$ and $\mathrm{T}$ is absolute temperature [34]. Figures $\mathbf{8 a}$ and $\mathbf{8 b}$ shows an abrupt drop of resistivity up to $10 \mathrm{KHz}$, and then the rate of fall 

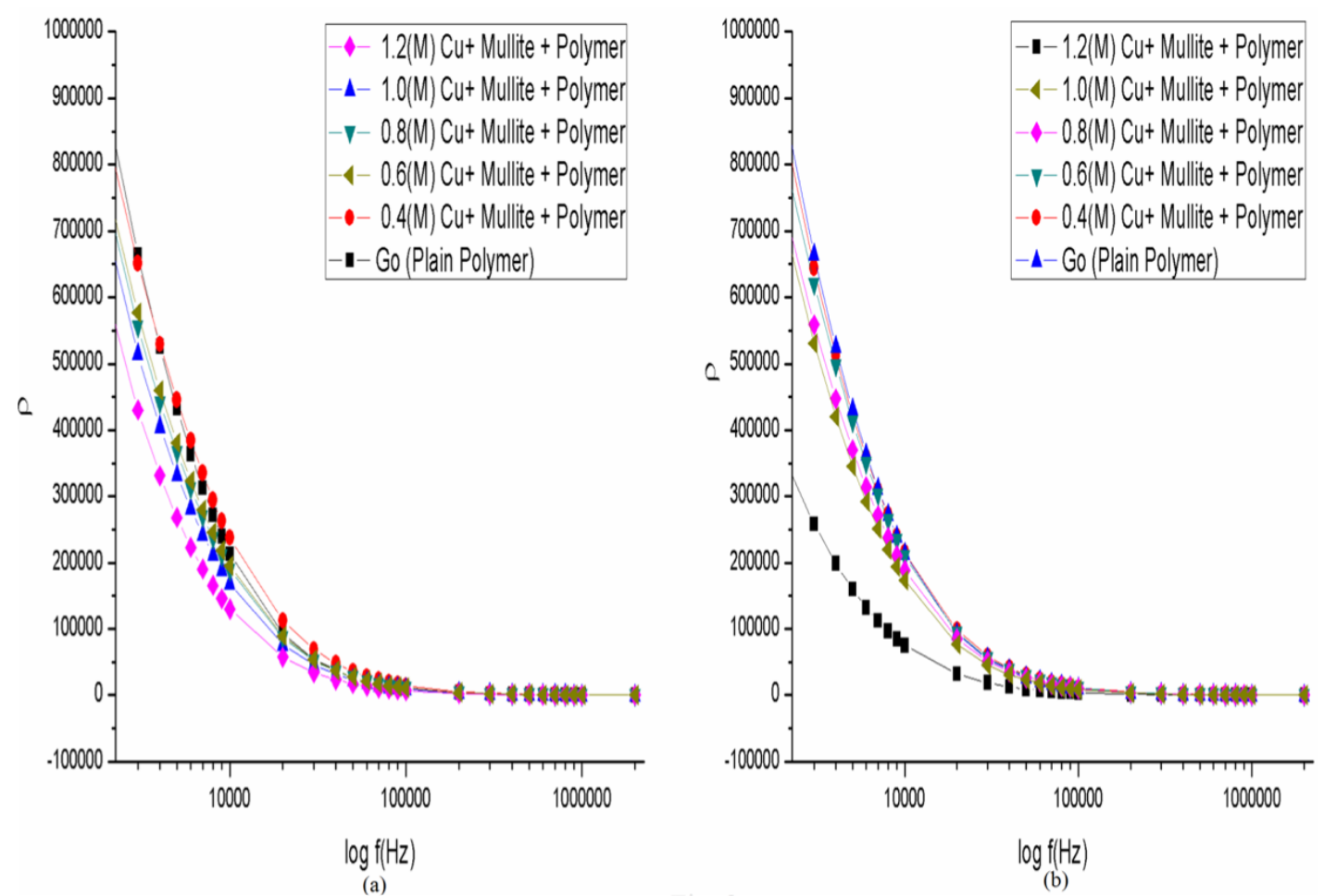

Figure 8: Frequency response of resistivity $(\Omega-\mathrm{cm})$ of copper ion doped mullite composite/polymer film along with undoped polymer film, where mullite precursor gels sintered at (a) $1100^{\circ} \mathrm{C}$ and (b) $1400^{\circ} \mathrm{C}$.

Table 1: Parameters Obtained from Dielectric, Electrical and Resistivity Analyses of Copper lon Doped Mullite Composite/Polymer Film along with Undoped Polymer Film, where Mullite Precursor Gels Sintered at $1100^{\circ} \mathrm{C}$ and $1400^{\circ} \mathrm{C}$

\begin{tabular}{|c|c|c|c|c|c|}
\hline \multirow{2}{*}{$\begin{array}{c}\text { Sintering } \\
\text { Temperature } \\
\text { of doped mullite } \\
\text { composite }\end{array}$} & Specimen & $\begin{array}{c}\text { Dielectric } \\
\text { Constant }\left(\varepsilon_{r}\right)\end{array}$ & $\begin{array}{l}\text { Dielectric Loss } \\
\quad(\tan \delta)\end{array}$ & $\begin{array}{l}\text { A.C. Conductivity } \\
\left(\sigma_{\text {a.c. }}\right)\end{array}$ & $\begin{array}{c}\text { Resistivity } \\
(\Omega-\mathrm{cm})\end{array}$ \\
\hline & Undoped Polymer $\left(\mathbf{G}_{0}\right)$ & 3.09168 & 0.1564 & $6.71343 \mathrm{E}^{-8}$ & 891246 \\
\hline \multirow{5}{*}{$\begin{array}{l}0 \\
0 \\
\circ \\
\end{array}$} & 0.4(M) Cu+Mullite +Polymer & 3.17016 & 0.26531 & $9.12112 \mathrm{E}^{-8}$ & 863017 \\
\hline & 0.6(M) Cu+Mullite +Polymer & 3.51633 & 0.28584 & $1.00765 \mathrm{E}^{-7}$ & 816789 \\
\hline & 0.8(M) Cu+Mullite +Polymer & 3.86007 & 0.33021 & $1.29436 \mathrm{E}^{-7}$ & 741503 \\
\hline & 1.0(M) Cu+Mullite +Polymer & 4.54428 & 0.33103 & $1.66866 \mathrm{E}^{-7}$ & 717299 \\
\hline & 1.2(M) Cu+Mullite +Polymer & 6.58166 & 0.41822 & $3.06088 \mathrm{E}^{-7}$ & 360567 \\
\hline \multirow{5}{*}{\begin{tabular}{l}
0 \\
$\circ$ \\
8 \\
\multirow{+}{+}{}
\end{tabular}} & 0.4(M) Cu+Mullite +Polymer & 3.80529 & 0.24729 & $1.25878 \mathrm{E}^{-7}$ & 851692 \\
\hline & 0.6(M) Cu+Mullite +Polymer & 3.86400 & 0.29296 & $1.27675 \mathrm{E}^{-7}$ & 771139 \\
\hline & 0.8(M) Cu+Mullite +Polymer & 6.10609 & 0.29990 & $2.36208 \mathrm{E}^{-7}$ & 754254 \\
\hline & 1.0(M) Cu+Mullite +Polymer & 12.67614 & 0.30173 & $3.48571 \mathrm{E}^{-7}$ & 706837 \\
\hline & 1.2(M) Cu+Mullite +Polymer & 19.96936 & 0.34788 & $6.65954 \mathrm{E}^{-7}$ & 608268 \\
\hline
\end{tabular}

in resistivity becomes lower. The drop in resistivity with frequency indicates the presence of glassy phase lamorphous phase in the mullite structure that may increase the mobility of the copper ion $\left(\mathrm{Cu}^{2+}\right)$, which finds an easy path to move and hence increases the electrical conductivity, keeping in mind that incorporation of transition metals in the periodic lattice of the mullite crystal structure helps in attaining a lower band structure [38].
Parameters obtained from dielectric, electrical and resistivity analyses are shown in Table 1.

\section{FESEM Analysis}

Figures 9 and 10 shows upper surface (a), fractured surface (b) along with their corresponding EDAX images (c) of doped mullite composite/polymer films with $1.2 \mathrm{M}$ concentration of copper doped mullite sintered at $1100^{\circ} \mathrm{C}$ and $1400^{\circ} \mathrm{C}$ respectively. 

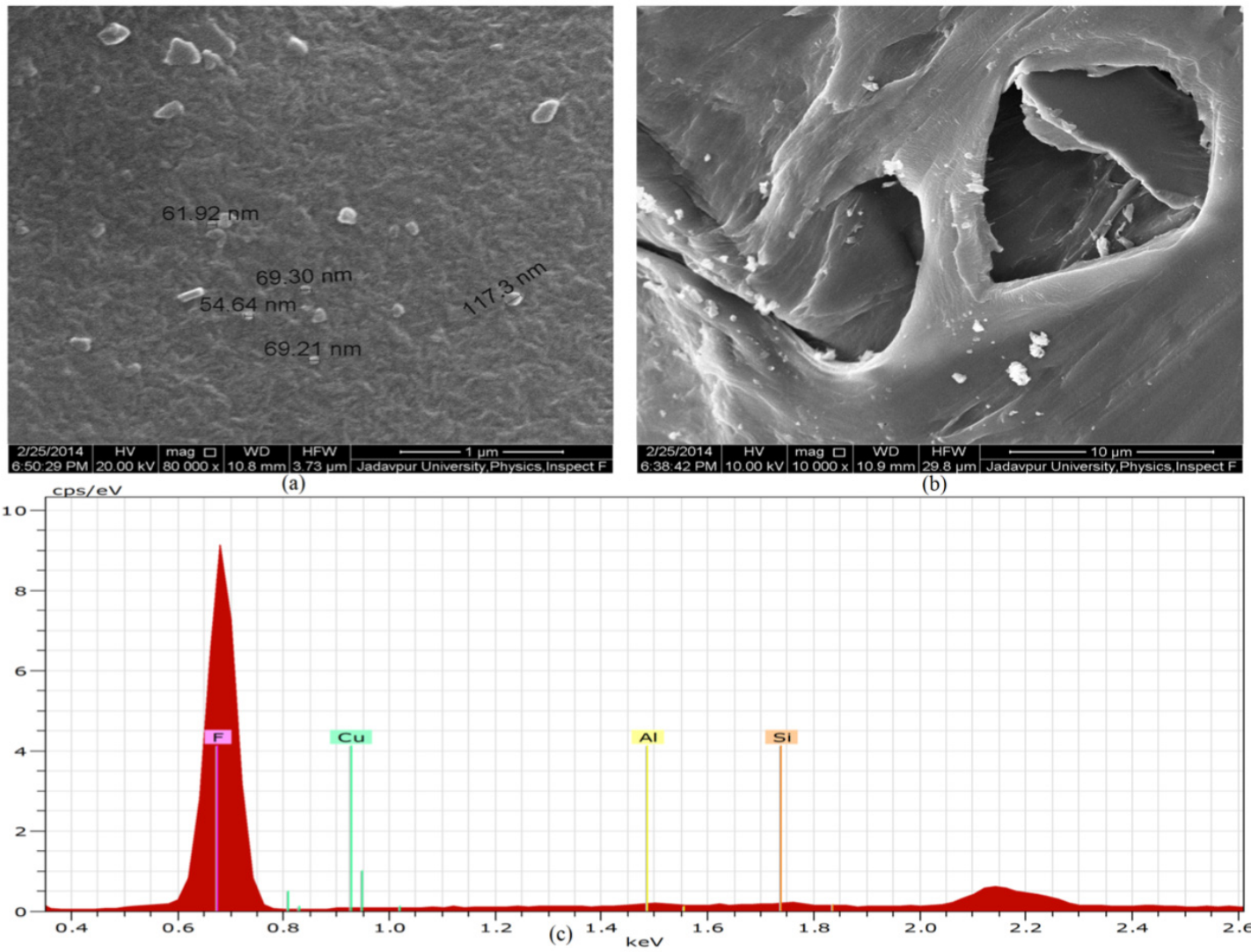

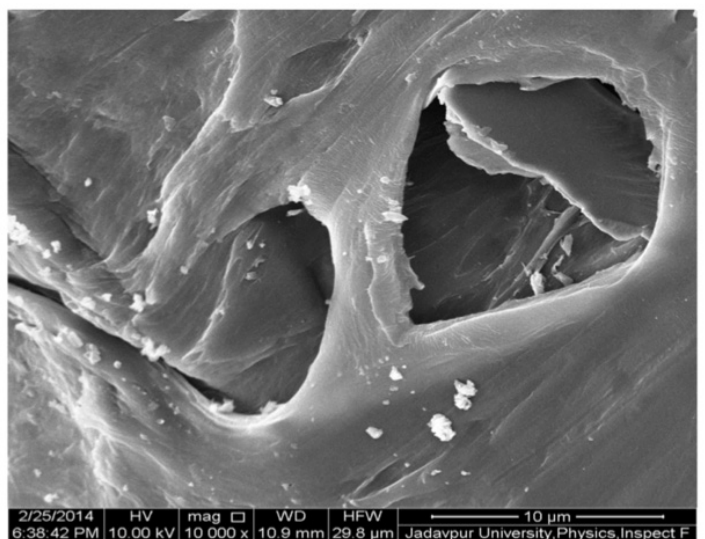

(b)

Figure 9: SEM images of upper surface (a), fractured surface (b) along with corresponding EDAX image (c) of doped mullite composite/polymer film with $1.2(\mathrm{M})$ concentration of copper doped mullite sintered at $1100^{\circ} \mathrm{C}$.
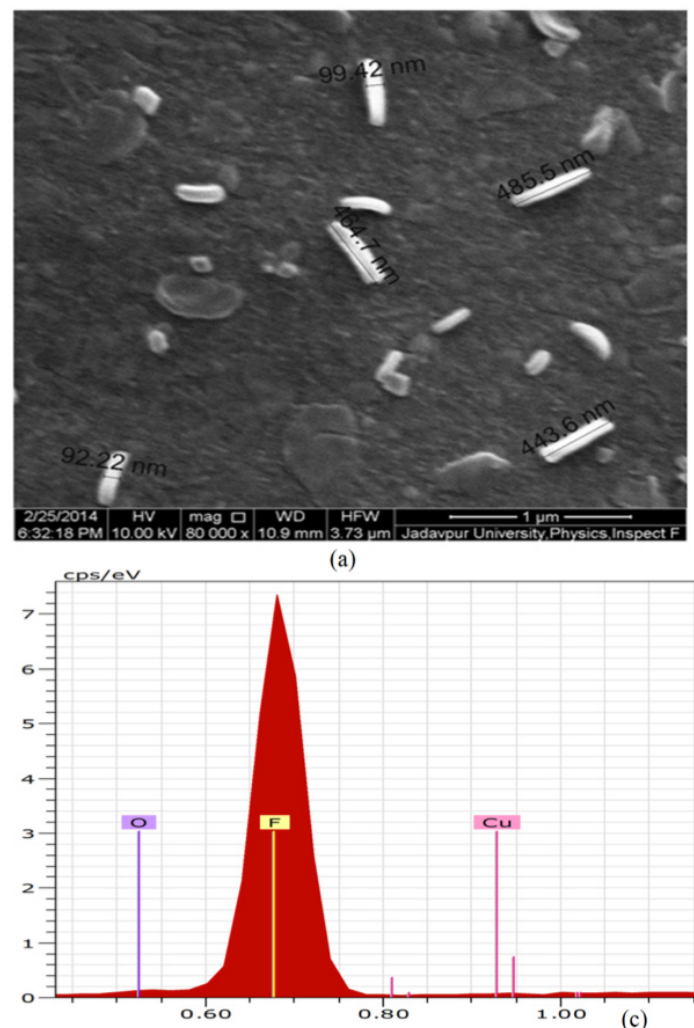

(a)

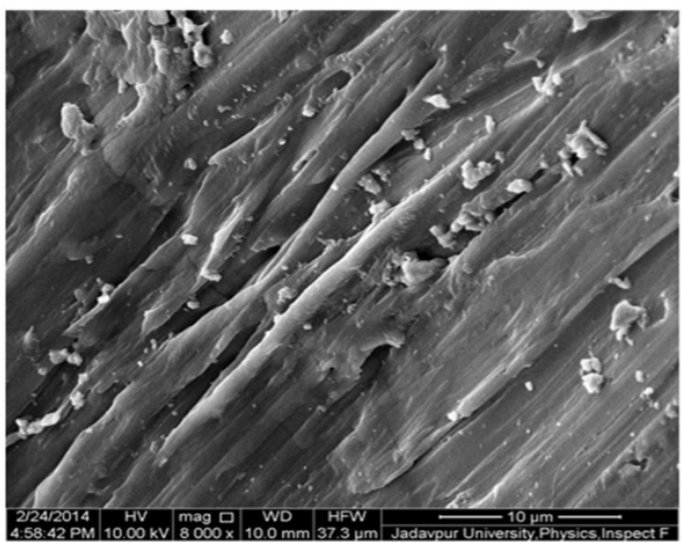

(b)

Figure 10: SEM images of upper surface (a), fractured surface (b) along with corresponding EDAX image (c) of doped mullite composite/polymer film with $1.2(\mathrm{M})$ concentration of copper doped mullite sintered at $1400^{\circ} \mathrm{C}$. 
Table 2: Parameters Obtained from EDAX Study with their Weight Percentages for 1.2 M Copper lon Doped Mullite Composite/Polymer Film Sintered at $1100^{\circ} \mathrm{C}$

\begin{tabular}{|c|c|c|c|c|c|c|}
\hline Element & $\begin{array}{c}\text { unn. C } \\
\text { [wt.\%] }\end{array}$ & $\begin{array}{c}\text { norm. C } \\
\text { [wt.\%] }\end{array}$ & $\begin{array}{c}\text { Atom. C } \\
\text { [at. \%] }\end{array}$ & $\begin{array}{c}\text { Compound } \\
\text { norm. }\end{array}$ & $\begin{array}{c}\text { Comp. C } \\
\text { [wt.\%] }\end{array}$ & $\begin{array}{c}\text { Error (3 Sigma) } \\
\text { [wt.\%] }\end{array}$ \\
\hline \hline Fluorine & 93.08 & 93.00 & 95.49 & & 93.00 & 35.09 \\
\hline Aluminium & 1.03 & 1.03 & 0.75 & $\mathrm{Al}_{2} \mathrm{O}_{3}$ & 1.95 & 0.36 \\
\hline Silicon & 0.77 & 0.77 & 0.54 & $\mathrm{SiO}_{2}$ & 1.65 & 0.27 \\
\hline Copper & 3.40 & 3.40 & 1.04 & & 3.40 & 0.00 \\
\hline Oxygen & 1.80 & 1.80 & 2.19 & & & 0.61 \\
\hline Total: & 100.08 & 100.00 & 100.00 & & \\
\hline
\end{tabular}

Table 3: Parameters Obtained from EDAX Study with their Weight Percentages for 1.2 M Copper lon Doped Mullite Composite/Polymer Film Sintered at $1400^{\circ} \mathrm{C}$

\begin{tabular}{|c|c|c|c|c|c|c|}
\hline Element & $\begin{array}{c}\text { unn. C } \\
\text { [wt.\%] }\end{array}$ & $\begin{array}{c}\text { norm. C } \\
\text { [wt.\%] }\end{array}$ & $\begin{array}{c}\text { Atom. C } \\
\text { [at.\%] }\end{array}$ & $\begin{array}{c}\text { Compound } \\
\text { norm. }\end{array}$ & $\begin{array}{c}\text { Comp. C } \\
\text { [wt.\%] }\end{array}$ & $\begin{array}{c}\text { Error (3 Sigma) } \\
\text { [wt.\%] }\end{array}$ \\
\hline \hline Fluorine & 89.63 & 91.34 & 93.76 & & 91.34 & 34.88 \\
\hline Oxygen & 2.71 & 2.76 & 3.36 & & 0.00 & 0.89 \\
\hline Copper & 3.15 & 3.21 & 0.99 & & 3.21 & 0.81 \\
\hline Aluminium & 1.18 & 1.20 & 0.87 & $\mathrm{Al}_{2} \mathrm{O}_{3}$ & 2.27 & 0.40 \\
\hline Silicon & 1.45 & 1.48 & 1.03 & $\mathrm{SiO}_{2}$ & 3.17 & 0.39 \\
\hline Total: & 98.13 & 100.00 & 100.00 & & & \\
\hline
\end{tabular}

It can be observed from the micrographs that, in case of copper doped mullite fired at $1100^{\circ} \mathrm{C}$ (Figure 9a), the spherical mullite particles are embedded in the polymer matrix, whereas, in case of Figure 10a, maximum number of needle shaped mullite particles takes place. Figures $\mathbf{9 b}$ and $\mathbf{1 0 b}$ are the evidences of doping, where images have been taken from the fractured field of the polymer. It can be clearly concluded from these images that, particles are doped in a well manner inside polymer matrix, which in turn affects its phase and electrical behavior.

The EDAX images (Figures 9c and 10c) confirm the presence of copper ion into polymeric system. Also the presence of $\mathrm{Al} \& \mathrm{Si}$ is the evidence of presence of mullite into polymer matrix. Elements obtained from EDAX study with their weight percentages are shown in Tables 2 and $\mathbf{3}$.

\section{CONCLUSION}

In this research work, the ceramic-polymer composites are investigated due to some important physical properties such as high dielectric constant, low dielectric loss, and high-energy storage density. Phase changes in polymer film have been observed, which were due to the contribution of copper doped mullite composite, evident from XRD, FTIR spectroscopy and FESEM characterizations. Within the frequency range studied, the role of doped mullite composite on polymer matrixwas found to enhance its electrical properties compared to that of pure polymer. The composite film showed maximum dielectric constant value of 19.96 at $1.0 \mathrm{KHz}$ for 1.2(M) copper doped mullite inside polymer matrix sintered at $1400^{\circ} \mathrm{C}$. The dielectric constant of the composites studied follows the logarithmic mixing rule and Maxwell-Wagner-Sillars (MWS) polarization theorem. A.C. conductivity increased with frequency and was found to depend on the amount of glassy phase and concentration of mobile ions present in the composites. With the increase in concentration of doped ceramic composite its resistivity was found to decrease. Moreover, it can be concluded that copper ion doped mullite composite has a positive impact on the polymer matrix, as it helps to change its phase behaviour, microstructure and increases electrical conductivity, which have potential application in many fields such as embedded capacitors, sensors, gate dielectrics, and electric energy storage devices applied in the electronics and electrical industry. 


\section{ACKNOWLEDGEMENT}

We are grateful to DST and UGC (PURSE program), Government of India, for the financial assistance.

\section{REFERENCES}

[1] Salimi A, Yousefi AA. Analysis Method: FTIR studies of $\beta-$ phase crystal formation in stretched PVDF films. Polym Test 2003; 22: 699-704. http://dx.doi.org/10.1016/S0142-9418(03)00003-5

Gregorio $\mathrm{Jr}$. R. Determination of the $\alpha, \beta$, and $y$ crystalline phases of poly(vinylidene fluoride) films prepared at different conditions. J Appl Polym Sci 2006; 100: 3272-9. http://dx.doi.org/10.1002/app.23137

[3] Lovinger AJ. Crystallization and morphology of melt-solidified poly(vinylidene fluoride). J Polym Sci B 1980; 18: 793-809.

[4] Yang JJ, Pan PJ, Hua L, Zhu B, Dong T, Inoue Y. Polymorphic crystallization and phase transition of poly(butylene adipate) in its miscible crystalline/crystalline blend with poly(vinylidene fluoride). Macromolecules 2010; 43: 8610-8

http://dx.doi.org/10.1021/ma1015566

[5] Sajkiewicz P, Wasiak A, Goclowski Z. Phase transitions during stretching of Poly(vinylidene fluoride). Eur Polym $\mathrm{J}$ 1999; 35: 423-9

http://dx.doi.org/10.1016/S0014-3057(98)00136-0

[6] Miller RJ. Single crystals of poly(vinylidene fluoride). Polym Sci Polym Chem 1976; 14: 2325-6. http://dx.doi.org/10.1002/pol.1976.180141216

[7] Cortili G, Zerbi G. Chain conformations of polyvinylidene fluoride as derived from its vibrational spectrum. Spectrochem Acta Part A: Mol Spectrosc 1967; 23: 285-99. http://dx.doi.org/10.1016/0584-8539(67)80231-9

[8] Dasgupta DK, Doughty KJ. Corona charging and the piezoelectric effect in polyvinylidene fluoride. Appl Phys 1978; 49: 4601-3.

http://dx.doi.org/10.1063/1.325441

[9] David GT, McKinney JE, Broadhurst MG, Roth SC. Electricfield-induced phase changes in poly (vinylidene fluoride). J Appl Phys 1978; 49: 4998-5002. http://dx.doi.org/10.1063/1.324446

[10] Welch GJ, Miller RL. Crystallization of poly(vinylidene fluoride): Equilibrium melting point and heat of fusion of the a-polymorph. J Polym Sci Polym Phys 1946; 14: 1683-92. http://dx.doi.org/10.1002/pol.1976.180140913

[11] Prest Jr. WM, Luca DJ. The formation of the $y$ phase from the $\alpha$ and $\beta$ polymorphs of polyvinylidene fluoride. J Appl Phys 1978; 49: 5042-7.

http://dx.doi.org/10.1063/1.324439

[12] Li YC, Tjong SC, Li RKY. Dielectric properties of binary polyvinylidene fluoride/barium titanate nanocomposites and their nanographite doped hybrids. Express Polym Lett 2011; 5: 526-34.

http://dx.doi.org/10.3144/expresspolymlett.2011.51

[13] Blythe T, David B. Electrical Properties of Polymers. $2^{\text {nd }}$ Ed. Cambridge University Press; 2005

[14] Dasgupta DK, Doughty KJ. Polymer-ceramic composite materials with high dielectric constants. Thin Solid Films 1988; 158: 93-105. http://dx.doi.org/10.1016/0040-6090(88)90306-9

[15] Huang $X$, Jiang $P$, Kim C, Liu F, Yin Y. Influence of aspect ratio of carbon nanotubes on crystalline phases and dielectric properties of poly(vinylidene fluoride). Euro Polym J 2009; 45: $377-86$

http://dx.doi.org/10.1016/j.eurpolymj.2008.11.018
[16] Patro TU, Mhalgi MV, Khakhar DV, Misra A. Studies on poly(vinylidene fluoride)-clay nanocomposites: Effect of different clay modifiers. Polymer 2008; 49: 3486-99. http://dx.doi.org/10.1016/i.polymer.2008.05.034

[17] Raja V, Sarma AK, Narasimha Rao VVR. Optical properties of pure and doped PMMA-CO-P4VPNO polymer films. Materials Lett 2003; 57: 4678-83. http://dx.doi.org/10.1016/S0167-577X(03)00384-7

[18] Podgrabinski T, Svorcik V, Mackova A, Hnatowicz V, Sajdl P. Dielectric properties of doped polystyrene and polymethylmethacrylate. J Mater Sci 2006; 17: 871-5.

[19] Huang XY, Jiang PK, Kim CU. Electrical properties of polyethylene/aluminum nanocomposites. J Appl Phys 2007; 102: 124103.

http://dx.doi.org/10.1063/1.2822336

[20] Roy D, Bagchi B, Das S, Nandy P. Electric and dielectric properties of sol-gel derived mullite doped with transition metals. Mater Chem Phys 2013; 138: 375-83. http://dx.doi.org/10.1016/j.matchemphys.2012.11.070

[21] Roy D, Bagchi B, Bhattacharya A, Das S, Nandy P. A Comparative study of densification of sol-gel-derived nanomullite due to the influence of iron, nickel and copper ions. Int J Appl Ceram Technol 2013; 1. http://dx.doi.org/10.1111/ijac.12114

[22] Priya L, Jog J. Poly (vinylidene fluoride)/clay nanocomposites prepared by melt intercalation: Crystallization and dynamic mechanical behavior studies. J Polym Sci Part B Polym Phys 2002; 40: 1682-9. http://dx.doi.org/10.1002/polb.10223

[23] Newman BA, Yoon CH, Pae KD. Piezoelectric activity and field-induced crystal structure transitions in poled poly(vinylidene fluoride) films. J Appl Phys 1979; 50: 6095. http://dx.doi.org/10.1063/1.325778

[24] Bagchi B, Das S, Bhattacharya A, Basu R, Nandy P. Mullite phase enhancement in Indian kaolins by addition of vanadium pentoxide. Appl Clay Sc 2010; 47: 409-13. http://dx.doi.org/10.1016/j.clay.2009.12.008

[25] Satapathy S, Gupta PK, Pawar S, Varma KBR. Effect of annealing on phase transition in poly(vinylidene fluoride) films prepared using polar solvent. Bull Mat Sc 2011; 34: 727-33. http://dx.doi.org/10.1007/s12034-011-0187-0

[26] Boccaccio T, Bottino A, Capanelli G, Piaggio P Characterization of PVDF membranes by vibrational spectroscopy. J Mem Sc 2002; 210: 315-29. http://dx.doi.org/10.1016/S0376-7388(02)00407-6

[27] Bormashenko Y, Pogreb R, Stanevsky O. [Bormasenko Ed], Vibrational spectrum of PVDF and its interpretation. Polymer Testing 2004, 23: 791-6. http://dx.doi.org/10.1016/j.polymertesting.2004.04.001

[28] Zhang YY, Jiang SL, Yu Y, Xiong G, Zhang QF, Guang GZ. Phase Transformation Mechanisms and Piezoelectric Properties of Poly (vinylidene fluoride) / Montmorillonite Composite. J Appl Polym Sci 2011; 123(5): 2595-600. http://dx.doi.org/10.1002/app.34431

[29] Padmaja P, Anilkumar GM, Mukundan P, Aruldhas, G Warrier KGK. Characterization of stoichiometric sol-gel mullite by Fourier transform infrared spectroscopy. Int J Inorg Mat 2001; 3: 693-8. http://dx.doi.org/10.1016/S1466-6049(01)00189-1

[30] Tang CW, Li B, Sun L, Lively B, Zhong WH. The effects of nanofillers, stretching and recrystallization on microstructure, phase transformation and dielectric properties in PVDF nanocomposites. Eur Polymer J 2012; 48: 1062-72. http://dx.doi.org/10.1016/i.eurpolymi.2012.04.002

[31] He F, ST L, Chan HLW, Fan JT. Preparation and characterization of porous poly(vinylidene fluoridetrifluoroethylene) copolymer membranes via electrospinning and further hot pressing. Adv Mat 2009; 21: 710-5. http://dx.doi.org/10.1002/adma.200801758 
[32] Dang ZM, Shen Y, Nan CW. Dielectric behavior of threephase percolative Ni-BaTiO 3 /polyvinylidene fluoride Composites. Applied Physics Letters 2002; 81: 4814-6. http://dx.doi.org/10.1063/1.1529085

[33] Kulek J, Szafraniak I, Hilczer B, Poomska M. Dielectric and pyroelectric response of PVDF loaded with $\mathrm{BaTiO} 3$ obtained by mechanosynthesis. J Non-Crystalline Solids 2007; 353: 4448-52.

http://dx.doi.org/10.1016/j.jnoncrysol.2007.02.077

[34] Cheng KC, Lin CM, Wang SF, Lin ST, Yang CF. Dielectric properties of epoxy resin-barium titanate composites at high frequency. Materials Lett 2007; 61: 757-60. http://dx.doi.org/10.1016/j.matlet.2006.05.061
[35] Newman BA, Scheinbeim JI, Yoon CH, Pae KD. Polarization Mechanisms in Phase 11 Poly(viny1idene fluoride) Films. Macromolecules 1983; 16: 60-8. http://dx.doi.org/10.1021/ma00235a012

[36] Jafar HI, Ali NA, Shawky A. Study of A.C electrical properties of aluminum-epoxy composites. J Al-Nahrain Univ 2011; 14 77-82.

[37] Gh. Abdulla O, Aziz BK, Saeed AO. Kaolin light concentration effects on the dielectric properties of polyvinyl alcohol films. Int J Sc and Adv Technol 2012; 2: 65-70.

[38] Thermal Conductivity, hyperphysics.phy-astr.gsu.edu/hbase/ thermo/thercond.html. 